\title{
PEMBERIAN TUNJANGAN KHUSUS DAERAH TERPENCIL UNTUK PERBAIKAN KINERJA GURU SMP DI KECAMATAN LIUKANG TUPABBIRING UTARA KABUPATEN PANGKEP
}

\author{
M. Ziaul Haq Hs
}

\begin{abstract}
Teacher is one of the crucial factors in learning; regardless how ideal the curriculum is, without any support of teachers' capability to implement the curriculum, it would not achieve the assigned educational goals. Teachers who devote themselves in areas categorized as $3 T$ (Outermost, Frontier, and Underdeveloped) require concerns from the government. The study aims to explain (1) How the provision of special allowances of remote areas to the junior high school teachers in the District of Northern Liukang Tupabbiring of Pangkep Regency, (2) How the performance of junior high school teachers in the District of Northern Liukang Tupabbiring of Pangkep Regency, (3) What impacts of providing special allowances of remote areas on the improvement of junior high school teachers' performance in the District of Northern Liukang Tupabbiring of Pangkep Regency.

The study was a field research situated in junior high schools in the District of Northern Liukang Tupabbiring of Pangkep Regency. The research subjects were junior high school teachers in the District of Northern Liukang Tupabbiring of Pangkep Regency. Interview, observation, and documentation were utilized in collecting the data which then verified by reducing the data, presenting them, and drawing conclusions. The study employed a multidisciplinary approach using qualitative data analysis consisting of three stages: (1) pre-field, (2) field work, (3) analysis.

The results revealed that the provision of special allowances of remote areas to the junior high school teachers in the District of Northern Liukang Tupabbiring of Pangkep Regency was still not evenly distributed. Most of the teachers, however, had got the allowances, while the junior high school teachers' performance in the District of Northern Liukang Tupabbiring of Pangkep Regency needed to be improved, and after giving the allowance, they were motivated to develop themselves and their performance as teachers in remote areas. The impacts of providing special allowances of remote areas in improving the junior high school teachers' performance in the District of Northern Liukang Tupabbiring of Pangkep Regency were as an additional income to overcome the difficulties of life for serving in remote areas, to boost the teachers' welfare in remote areas, so the quality of education in remote areas could compete with the education in urban areas.
\end{abstract}


The implications of this study were teachers expected that there were equitable distribution to all teachers who were entitled to special allowances in remote areas, as well as providing them with the ease of continuing education to improve their competence in order to become creative and insightful teachers.

Keywords: Remote Areas, Curriculum, Learning, Special Allowances

\begin{abstract}
ABSTRAK
Guru merupakan salah satu faktor penting dalam pembelajaran, bagaimanapun idealnya suatu kurikulum tanpa ditunjang oleh kemampuan guru untuk mengimplementasikannya maka kurikulum tersebut tidak akan mencapai tujuan pendidikan yang telah dirumuskan. Guru yang mengabdikan diri di daerah yang termasuk dalam kategori $3 \mathrm{~T}$ (Terluar, Terdepan dan Tertinggal) perlu mendapat perhatian dari pemerintah. Sehigga dalam penelitian ini bertujuan menjelaskan (1) Bagaimana pemberian tunjangan khusus daerah terpencil kepada guru-guru SMP di Kecamatan Liukang Tupabbiring Utara Kabupaten Pangkep, (2) Bagaimana kinerja guru SMP di Kecamatan Liukang Tupabbiring Utara Kabupaten Pangkep, (3) Bagaimana dampak pemberian tunjangan khusus daerah terpencil dalam perbaikan kinerja guru SMP di Kecamatan Liukang Tupabbiring Utara Kabupaten Pangkep.

Penelitian ini merupakan penelitian lapangan (field research) yang berlokasi di SMP dalam wilayah Kecamatan Liukang Tupabbiring Utara Kabupaten Pangkep . Subjek penelitian terdiri atas guru-guru SMP di Liukang Tupabbiring Utara Kabupaten Pangkep. Adapun metode pengumpulan data melalui wawancara, observasi, dan dokumentasi. Analisis data diverifikasi dengan cara mereduksi data, menyajikan data, dan menarik kesimpulan. Pendekatan penelitian ini menggunakan pendekatan multidisipliner dengan menggunakan analisis data kualitatif yang meliputi tiga tahap: (1) pra-lapangan, (2) pekerjaan lapangan, (3) analisis.

Hasil penelitian menunjukkan bahwa pemberian tunjangan khusus daerah terpencil kepada guru-guru SMP di Kecamatan Liukang Tupabbiring Utara Kabupaten Pangkep masih belum merata. Tetapi sebagian besar guru sudah pernah mendapatkan tunjangan, adapun kinerja guru SMP di Kecamatan Liukang Tupabbiring Utara Kabupaten Pangkep perlu ditingkatkan, dan setelah pemberian tunjangan menjadi motivasi untuk mengembangkan diri dan kinerjanya sebagai guru di daerah terpencil. Dampak pemberian tunjangan khusus daerah terpencil dalam meningkatkan kinerja guru SMP di Kecamatan Liukang Tupabbiring Utara Kabupaten Pangkep adalah sebagai tambahan penghasilan untuk mengatasi
\end{abstract}


kesulitan hidup selama bertugas di daerah terpencil, mendorong peningkatan kesejahteraan guru daerah terpencil, sehingga kualitas pendidikan di daerah terpencil mampu bersaing dengan pendidikan di perkotaan.

Implikasi penelitian ini, guru mengharapkan adanya pemerataan bagi semua guru yang berhak mendapatkan tunjangan khusus di daerah terpencil dan guru diberikan kemudahan melanjutkan pendidikan untuk meningkatkan kompetensinya sehingga mampu menjadi guru yang kreatif dan berwawasan luas.

Kata Kunci: Daerah Terpencil, Kurikulum, Pembelajaran, Tunjangan

\section{PENDAHULUAN}

\section{Latar Belakang Masalah}

Guru merupakan salah satu faktor penting dalam pembelajaran, bagaimanapun idealnya suatu kurikulum tanpa ditunjang oleh kemampuan guru untuk mengimplementasikannya maka kurikulum tersebut tidak akan mencapai tujuan pendidikan yang telah dirumuskan. Dalam ruang lingkup persekolahan, guru menjadi figur sentral dari segala upaya pembaruan pendidikan.

Guru adalah tumpuan harapan untuk mewujudkan agenda-agenda pendidikan nasional, utamanya dalam hal peningkatan mutu dan relevansi, pemerataan dan perluasan kesempatan, dan peningkatan efisiensi. ${ }^{1}$ Apabila kinerja keseluruhan komponen sekolah, peserta didik dan bahkan pendidikan secara nasional kurang memuaskan, seringkali masyarakat menjadikan guru sebagai sasaran yang dianggap paling bertanggung jawab.

Dalam Undang-undang Republik Indonesia Nomor 14 tahun 2005 tentang Guru dan Dosen dikemukakan bahwa :

Guru adalah pendidik profesional dengan tugas utama mendidik, mengajar, membimbing, mengarahkan, melatih, menilai dan mengevaluasi peserta didik pada pendidikan anak usia dini, jalur pendidikan formal, pendidikan dasar, dan pendidikan menengah. ${ }^{2}$

Sebagai figur sentral dalam pendidikan, guru yang profesional adalah guru yang memiliki seperangkat kompetensi (pengetahuan, keterampilan, dan perilaku) yang harus dimiliki, dihayati dan dikuasai oleh guru dalam melaksanakan tugas keprofesionalannya. Kompetensi yang harus dimiliki oleh guru berdasarkan Undang-Undang Nomor 14 Tahun 2005 tentang Guru dan Dosen pada Bab IV

\footnotetext{
${ }^{1}$ Ali Mudlofir, Pendidik Profesional: Konsep, Strategi, dan Aplikasinya Dalam Peningkatan Mutu Pendidikan di Indonesia (Cet. II; Rajawali Pers: Jakarta, 2013), h. 61.

${ }^{2}$ Republik Indonesia, Undang-Undang RI Nomor 14 Tahun 2005 tentang Guru dan Dosen. (Jakarta: Sinar Grafika, 2005), h. 5.
} 
Pasal 10 ayat 91), yang menyatakan bahwa : Kompetensi guru meliputi kompetensi pedagogik, kompetensi kepribadian, kompetensi sosial, dan kompetensi profesional yang diperoleh melalui pendidikan kompetensi. ${ }^{3}$ Empat jenis kompetensi ini adalah persyaratan dasar sehingga seseorang layak untuk mengemban amanah sebagai pendidik.

Keberhasilan mereka dalam menjalankan fungsinya dipengaruhi oleh kemampuan profesional, sikap dan orientasi; kesejahteraan, dan fasilitas serta komitmen terhadap visi dan misi. ${ }^{4}$ Faktor kesejahteraan yang tidak merata dikalangan guru seringkali menjadi penyebab terhadap lambatnya pencapaian kinerja guru, utamanya menyangkut pemerataan kesejahteraan antara guru yang mengabdikan diri di daerah terpencil dengan guru yang mengajar di daerah perkotaan.

Begitu besarnya perhatian Islam terhadap pendidikan, hingga Islam mewajibkan setiap pemeluknya tidak hanya menuntut ilmu tapi juga mengajarkan pengetahuan yang dimiliki sesuai dengan kemampuan masing-masing. Sesuai dengan fungsi pendidikan nasional untuk mengembangkan kemampuan dan membentuk watak serta peradaban bangsa yang bermartabat dalam rangka mencerdaskan kehidupan bangsa, bertujuan untuk berkembangnya potensi peserta didik agar menjadi manusia yang beriman dan bertaqwa kepada Tuhan Yang Maha Esa, berakhlak mulia, sehat berilmu, cakap, kreatif, mandiri dan menjadi warga negara yang demokratis serta bertanggung jawab. Untuk mencapai tujuan tersebut menjadi tanggung jawab kita bersama bukan hanya guru semata tetapi juga pemerintah dan masyarakat.

Guru sebagai figur sentral pendidikan menjadi ujung tombak dari keberhasilan pendidikan, guru yang notabene sebagai manusia biasa juga memiliki berbagai kebutuhan hidup sehari-hari yang semestinya terpenuhi, dibutuhkan keseimbangan antara hak untuk mendapatkan kesejahteraan dan kewajiban untuk menunaikan tugas pokoknya sebagai pengajar di sekolah. Kualitas dan kuantitas pengajaran bisa dituntut agar dipenuhi oleh guru yang bersangkutan sepanjang mereka juga mendapatkan hak kesejahteraan yang layak untuk memenuhi hajat hidup dirinya dan keluarganya.

Fenomena guru yang mengabdikan diri di daerah yang termasuk dalam kategori $3 \mathrm{~T}$ (Terluar, Terbelakang dan Terpencil) akhir-akhir ini sering menjadi sorotan publik, baik di media cetak maupun media elektronik. Mereka yang

\footnotetext{
${ }^{3}$ Ali Mudlofir, Pendidik Profesional : Konsep, Strategi, dan Aplikasinya Dalam Peningkatan Mutu Pendidikan di Indonesia., h. 75.

${ }^{4}$ Ahmad Baedowi, Calak Edu Esai-esai Pendidikan 2012-2014 (Cet. I; Jakarta; PT. Pustaka Alvabet, 2015), h. 19.
} 
mengabdikan dirinya di daerah terpencil selama ini kurang mendapatkan perhatian yang layak dari pemerintah, bahkan cenderung diabaikan dan terlupakan. Hak-hak sebagai guru yang berkaitan dengan pemenuhan kebutuhan rumah dinas yang layak, alat transportasi yang aman dan tunjangan khusus daerah terpencil selama ini belum merata dinikmati oleh semua guru.

Secara umum terdapat beberapa problematika pendidikan yang terjadi di daerah terpencil, diantaranya adalah; sulitnya penempatan tenaga pendidik yang bersedia mengabdikan diri di daerah terpencil, keterbatasan biaya pendidikan untuk menunjang kelengkapan sarana pembelajaran, sarana pendidikan yang masih jauh dari standar kelayakan, akses informasi dan komunikasi yang sangat terbatas. Tuntutan kurikulum nasional yang mewajibkan pelaksanaan waktu pembelajarn secara maksimal seringkali masih terkendala dengan kondisi ketersediaan tenaga pendidik yang minim untuk melaksanakan proses pembelajaran.

Di berbagai wilayah terpencil atau perbatasan, jumlah tenaga guru di setiap sekolah semakin berkurang. Tetapi pada kawasan kota dan pinggiran kota, jumlah guru yang ada tidak sebanding dengan beban mengajarnya. Jika di wilayah terpencil dan perbatasan memiliki jumlah guru sedikit sehingga mereka memiliki beban kerja yang tinggi, maka sebaliknya di kawasan kota dan atau pinggiran kota memiliki jumlah guru yang relatif banyak tetapi beban kerja sedikit. ${ }^{5}$

Terkhusus di wilayah Kepulauan Kabupaten Pangkep, terdapat 4 (empat) kecamatan yang berstatus sebagai daerah kepulauan dan terpencil, yaitu Kecamatan Liukang Tupabbiring, Kecamatan Liukang Tupabbiring Utara, Kecamatan Liukang Kalmas, dan Kecamatan Liukang Tangayya. Keempat kecamatan ini memiliki puluhan pulau yang diantaranya ada yang berpenghuni dan adapula yang belum di huni oleh manusia.

Kebijakan pemberian tunjangan khusus daerah terpencil bagi guru yang diberikan berdasarkan landasan hukum Peraturan Pemerintah Nomor 41 Tahun 2009 Tentang Tunjangan Profesi Guru dan Dosen, Tunjangan Khusus Guru dan Dosen, serta Tunjangan Kehormatan Professor yang kemudian dijabarkan secara teknis dalam Peraturan Menteri Pendidikan Nasional Nomor 34 Tahun 2012. Yang berjumlah satu kali gaji pokok bagi PNS dipotong pajak PPh dan bagi guru Non PNS jumlahnya ditentukan sebesar Rp. 1.500.000/bulan.

Pemberian tunjangan khusus tersebut diharapkan menjadi suplemen yang mendorong agar guru-guru yang bertugas di daerah terpencil terpenuhi hak kesejahteraannya dan berusaha sebaik mungkin untuk meningkatkan efektifitas

\footnotetext{
${ }^{5}$ Onisimus Amtu, Membenahi Pendidikan di Wilayah Kepulauan. (Cet. I; Bandung: CV. Alfabeta, 2014), h. 26.
} 
kinerjanya, utamanya pada aspek kuantitas pengajaran dan juga kualitas pengajaran.

Pada kenyataannya, dari berbagai kondisi yang penulis saksikan di lapangan, ditambah dengan beberapa informasi yang beredar terkait distribusi tunjangan khusus terpencil bagi guru-guru SMP di wilayah Kecamatan Liukang Tupabbiring Utara masih terdapat berbagai masalah. Di antaranya adalah tidak meratanya distribusi tunjangan khusus tersebut, pola rekrutment penerima tunjangan khusus yang masih sering menimbulkan polemik, adanya kesenjangan yang terjadi antara penerima dan yang tidak menerima, dampak pemberian tunjangan khusus terhadap perbaikan disiplin kerja guru dan kondisi etos kerja guru yang menerima dana tunjangan khusus terpencil tersebut.

Selain faktor alam dan keterbatasan transportasi yang dialami oleh tenaga pendidik di daerah kepulauan, terdapat faktor lain yang menjadi kendala dalam peningkatan mutu pendidikan di daerah kepulauan, yaitu 1) Kurangnya kedisiplinan tenaga pendidik, yang mengakibatkan proses belajar mengajar tidak maksimal dilaksanakan setiap harinya. 2) kurangnya motivasi kerja tenaga pendidik dan tenaga kependidikan, hal ini sangat mempengaruhi impelementasi program sekolah yang telah dicanangkan dalam satu tahun pelajaran. 3) Kurangnya komitmen tenaga pendidik untuk meningkatkan kualitas pembelajaran dan juga kompetensinya untuk mencapai mutu pendidikan yang lebih baik.

\section{A. Rumusan Masalah}

Berdasarkan identifikasi dan pembatasan masalah tersebut, maka ditentukan rumusan masalah yaitu "Bagaimana pemberian tunjangan khusus daerah terpencil untuk perbaikan kinerja guru SMP di Kecamatan Liukang Tupabbiring Kabupaten Pangkep". Dan dirumuskan dalam beberapa sub masalah sebagai berikut:

1. Bagaimana proses pemberian tunjangan khusus daerah terpencil kepada guru-guru SMP di Kecamatan Liukang Tupabbiring Utara Kabupaten Pangkep?

2. Bagaimana kinerja guru SMP di Kecamatan Liukang Tupabbiring Utara Kabupaten Pangkep?

3. Bagaimana dampak pemberian tunjangan khusus daerah terpencil dalam perbaikan kinerja guru SMP di Kecamatan Liukang Tupabbiring Utara Kabupaten Pangkep?

Untuk menjawab rumusan di atas, penulis melakukan penelitian kualitatif yaitu menggunakan analisis deskriptif kualitatif dan bersifat induktif, pembahasan 
dilaksanakan dengan cara diawali pada penelusuran yang bertitik tolak pada pengamatan yang bersifat khusus kemudian mengambil kesimpulan yang bersifat umum.

Adapun kajiannya menggunakan analisis kualitatif yakni data yang terkumpul berbentuk kata-kata yang digunakan secara naratif. ${ }^{6}$ Metode penelitian kualitatif ini sering disebut metode penelitian naturalistik karena penelitiannya dilakukan dalam kondisi yang alamiah (natural setting). ${ }^{7}$

Penulis melakukan penelitian yang berlokasi di Kecamatan Liukang Tupabbiring Utara. Penelitian ini secara spesifik dilaksanakan di 4 (empat) Sekolah Menengah Pertama (SMP) yang berstatus Negeri yaitu, SMPN 4 Satap Liukang Tupabbiring Utara, SMPN 5 Satap Liukang Tupabiring Utara, SMPN 6 Satap Liukang Tupabbiring Utara, SMPN 10 Satap Liukang Tupabbiring Utara. Dengan pertimbangan rasio tenaga pendidik yang menerima tunjangan khusus daerah terpencil lebih banyak tersebar di empat sekolah tersebut, perbandingan rasio jumlah tenaga pendidik dan peserta didik yang cukup memadai.

Pendekatan, adalah perspektif makro yang dipakai dalam melihat fenomena yang diteliti. ${ }^{8}$ Dalam menelaah permasalahan tesis ini, peneliti menggunakan pendekatan metodologis dan pendekatan keilmuan. Adapun sumber data yang digunakan adalah data primer atau data utama yang diambil langsung dari informan, yaitu pendidik (guru), peserta didik dan pemerintah daerah dalam hal ini adalah Dinas Pendidikan Olahraga dan Pemuda. Data Sekunder merupakan data yang berhubungan dengan kondisi yang objektif di Kecamatan Liukang Tupabbiring Utara, dalam penelitian ini dibutuhkan data yang tertulis yang menjadi landasan teori untuk mendukung data lapangan. Data ini berhubungan dengan keadaan Pendidik, pegawai/staf, keadaan peserta didik, serta sarana dan prasarana.

Penelitian ini menggunakan teknik observasi, wawancara, dan studi dokumen atau catatan yang ada di Dinas Pendidikan, sekolah SMP Negeri maupun swasta yang berada dalam wilayah Kecamatan Liukang Tupabbiring Utara.

Instrumen penelitian yang digunakan dalam tesis ini adalah peneliti sendiri sebagai human instrument, dalam hal ini peneliti sendiri sebagai instrument kunci, peneliti berfungsi menetapkan fokus penelitian, memilih informan sebagai sumber data, menilai kualitas data, menganalisis data, menafsirkan data dan membuat

\footnotetext{
${ }^{6}$ Nana Syaodiah Sukmadinata, Metode Penelitian Pendidikan (Cet. III; Remaja Rosdakarya, 2007) h. 60.

${ }^{7}$ Sugiyono, Memahami Peneltian Kualitatif, (Cet. I: Bandung; CV. Alfabeta, 2005) h. 1

${ }^{8}$ Pascasarjana UIN Alauddin Makassar, Pedoman Penulisan Karya Ilmiah Tesis dan Disertasi. Edisi Revisi, Tahun 2013., h. 33
} 
kesimpulannya dan instrument tambahan berupa pedoman observasi, pedoman wawancara (interview), dan format catatan dokumentasi.

\section{PEMBAHASAN}

Pemberian Tunjangan Khusus Daerah Terpencil Pada Guru SMP Di Kecamatan Liukang Tupabbiring Utara Kabupaten Pangkep

Indonesia adalah salah satu negara kepulauan dengan tingkat keragaman yang menjadi kekayaan sekaligus kebanggaan bersama. Sebagai negara berbentuk kepulauan, masyarakat Indonesia hidup dan menyebar pada pulau-pulau besar dan kecil, memiliki konsep dan situasi yang berbeda-beda. Keragaman kultur budaya, suku, agama, bahasa, dan sebagainya menunjukkan bahwa setiap kelompok masyarakat dengan konteks dan situasi tertentu, memerlukan perlakuan khusus dalam pertimbangan pelaksanaan program pembangunan termasuk di dalamnya pemerataan layanan pendidikan.

Sejak otonomi daerah diimplementasikan, pemerintah dan masyarakat menjadi yakin bahwa akan terjadi peningkatan dan perkembangan dalam aspek layanan dan mutu hasil pembelajaran. Salah satu kondisi faktual yang dihadapi masyarakat khususnya yang menetap di wilayah kepulauan adalah keterjangkauan untuk mangakses pendidikan yang bermutu dan penyediaan sarana dan prasarana pembelajaran yang belum memadai.

Pada daerah-daerah dengan gugus pulau yang luas, setiap kebutuhan dan kendala yang dihadapi masyarakat memerlukan proses identifikasi dan analisis kondisi lingkungan. Permasalahan yang dihadapi masyarakat di wilayah kepulauan ada yang seragam namun tidak sedikitpula yang sifatnya kasuistik. Diperlukan perhatian serius pemerintah terhadap pemenuhan sarana dan prasarana umum, jarak antar pulau yang cukup jauh memerlukan sarana transportasi yang memadai termasuk pemberian tunjangan khusus untuk meningkatkan kualitas pendidikan.

Pemberian Tunjangan Khusus bagi guru daerah terpencil, disambut baik oleh Kementerian Pendidikan dan Kebudayaan (Kemendikbud). Hal ini seperti yang dilansir dari Republika (17/02/2015), Kemendikbud memberi dukungan penuh kepada daerah yang memberikan tunjangan khusus lebih bagi guru. Pasalnya, hal tersebut sangat dibutuhkan untuk meningkatkan kesejahteraan bagi guru daerah terpencil. Dengan harapan, kesejahteraan itu akan bertimbal balik terhadap kinerja yang lebih baik tanpa berfikir untuk secepatnya pulang ke kampung halaman bagi guru daerah terpencil yang berstatus pendatang.

Berdasarkan hasil observasi penulis, adapun mekanisme pemberian tunjangan khusus daerah terpencil melalui tahapan sebagai berikut:

1. Pengusulan oleh pihak sekolah kepada Dinas Pendidikan 
2. Validasi data guru melalui aplikasi DAPODIK oleh operator sekolah

3. Verifikasi data oleh Dinas Pendidikan berdasarkan kriteria yang tercantum pada Petunjuk Teknis

4. Pengusulan oleh Dinas Pendidikan kepada Kementerian Pendidikan dan Kebudayaan berdasarkan jumlah kuota yang tersedia.

5. Daftar guru penerima tunjangan diterbitkan bersama dengan nomor rekening pada bank yang ditunjuk.

Menurut Bapak Takdir dalam wawancara dengan penulis bahwa pemberian tunjangan khusus daerah terpencil di Kecamatan Liukang Tupabbiring Kabupaten Pangkep seharusnya bisa dinikmati oleh semua teman-teman yang mengajar di daerah terpencil, yang menjadi masalah adalah masih ada sebagian teman-teman yang belum bisa menerima tunjangan. ${ }^{9}$

Sedangkan menurut bapak Syamsuddin Nyonri mengatakan bahwa pemberian tunjangan khusus daerah terpencil di Kecamatan Liukang Tupabbiring Utara Kabupaten Pangkep sudah sesuai dengan proses sistem dapodik untuk mendapatkan tunjangan. Ini dilihat karena sudah sebagian teman-teman sudah mendapatkan tunjangan khusus daerah terpencil. ${ }^{10}$

Pernyataan senada juga dikemukakan oleh ibu Zulharyani $\mathrm{H}$, mengatakan bahwa pemberian tunjangan khusus daerah terpencil di Kecamatan Liukang Tupabbiring Utara Kabupaten Pangkep dalam 2 tahun terakhir ini sudah mulai merata dan transparan. ${ }^{11}$

Oleh karena itu, dengan adanya tunjangan khusus bagi guru daerah terpencil diharapkan bisa memperlancar proses pembelajaran di daerah terpencil. Tunjangan khusus itu dapat dimanfaatkan oleh guru daerah terpencil untuk membeli alat peraga pendukung pembelajaran dan fasilitas lainnya yang dibutuhkan sesuai dengan kondisi lapangan. Sehingga, kualitas lulusan yang dihasilkan dari daerah terpencil tidak terlalu berbeda dengan lulusan di perkotaan. ${ }^{12}$

Menurut Bapak Sapril Mahmud, hal-hal yang perlu diperhatikan pemerintah dalam proses pemberian tunjangan khusus adalah (1) pemberian tunjangan khusus harus merata dan transparan, jika pemberian tunjangan khusus belum merata maka

\footnotetext{
${ }^{9}$ Takdir, Guru di SMPN 5 Kecamatan Liukang Tupabbiring Utara Kabupaten Pangkep, Wawancara, Pangkep 20 Juli 2016.

${ }^{10}$ Syamsuddin Nyonri, Guru di SMPN 5 Kecamatan Liukang Tupabbiring Utara Kabupaten Pangkep, Wawancara, Pangkep 30 Mei 2016.

${ }^{11}$ Zulharyani, Guru di SMPN 5 Kecamatan Liukang Tupabbiring Utara Kabupaten Pangkep , Wawancara, Pangkep 24 Juli 2016.

${ }^{12}$ Takdir, Guru di SMPN 5 Kecamatan Liukang Tupabbiring Utara Kabupaten Pangkep , Wawancara, Pangkep 20 Juli 2016.
} 
dikhawatirkan ada kecemburuan antar sesama guru yang belum mendapatkan tunjangan. (2) syarat pemberian tunjangan khusus perlu dipermudah. ${ }^{13}$

Berdasarkan temuan penulis dilapangan, pemberian tunjangan khusus daerah terpencil yang diberikan kepada guru belum dilakukan secara merata. Kondisi tersebut terlihat dari jumlah penerima dimasing-masing sekolah yang belum menyentuh keseluruhan tenaga pendidik dan tenaga kependidikan. Misalnya jumlah penerima di SMPN 5 Satap Liukang Tupabbiring Utara pada tahun pelajaran 2015/2016 masih berjumlah 3 orang dari 7 guru yang memiliki NUPTK. Kondisi tersebut tidak berbeda jauh dengan sekolah SMP/sederajat lainnya yang berada dalam wilayah Kecamatan Liukang Tupabbiring Utara.

Terkait dengan kesinambungan, penulis menemukan pemberian tunjangan khusus daerah terpencil masih belum terlaksana secara berkesinambungan. Misalnya, guru yang mendapatkan tunjangan pada tahun 2015 ternyata tidak mendapatkan tunjangan yang sama pada tahun 2016. Hal tersebut disebabkan oleh jumlah kuota penerima setiap tahun selalu berubah. Setelah penulis menelusuri hingga ke pihak terkait dalam hal ini adalah Dinas Pendidikan setempat, perubahan itu bukan disebabkan oleh kebijakan program dari Dinas Pendidikan, akan tetapi perubahan jumlah kuota penerima ditentukan langsung oleh Kementerian Pendidikan dan Kebudayaan, sehingga Dinas Pendidikan tidak memiliki kewenangan untuk menambah ataupun mengurangi jumlah penerima Tunjangan setiap tahunnya.

Penulis juga menemukan fakta bahwa tunjangan khusus daerah terpencil belum diatur secara khusus dalam Peraturan Daerah (Perda), sehingga distribusinya tidak merata kepada guru-guru yang bertugas didaerah terpencil yang tersebar di empat kecamatan kepulauan yaitu kecamatan Liukang Tupabbiring, kecamatan Liukang Tupabbiring Utara, pulau terluar yaitu kecamatan Liukang Kalmas yang berbatasan dengan Propinsi Kalimantan Selatan dan Kecamatan Liukang Tangayya yang berbatasan dengan Propinsi Jawa Timur/pulau madura disebelah selatan dan Propinsi Nusa Tenggara Barat disebelah barat.

\section{B. Kinerja Guru SMP di Kecamatan Liukang Tupabbiring Utara Kabupaten Pangkep}

Pada era globalisasi sekarang ini pendidikan menjadi sangat penting. Bekal pendidikan yang sudah dimiliki suatu masyarakat akan berkembang secara baik dan diharapkan mampu bersaing secara kompetetif di era persaingan yang semakin

${ }^{13}$ Sapril Mahmud, Kepala Sekolah SMP 10 Kecamatan Liukang Tupabbiring Utara Kabupaten Pangkep, Wawancara, Pangkep 10 Mei 2016. 
ketat. Dalam suasana kompetetif semacam ini diperlukan sumber daya manusia yang berkualitas, yaitu sumber daya manusia yang mampu menghadapi persaingan dan terampil dalam berbagai aktivitas kehidupan.

Sumber daya manusia berkualitas dapat diciptakan melalui lembaga pendidikan formal yaitu sekolah. Dalam upaya mengantarkan generasi anak bangsa untuk mampu bersaing dalam kompetisi global yang kian hari semakin ketat. Dalam mendukung cita-cita bangsa Indonesia yaitu mencerdaskan generasi muda khususnya di bangku sekolah, maka diperlukan peningkatan kinerja guru ke arah yang lebih baik sebab guru memilki pengaruh yang besar dalam hal ini, termasuk kinerja guru yang ada di daerah terpencil.

Guru sangat menentukan keberhasilan pendidikan suatu negara. Berbagai kajian dan hasil penelitian menggambarkan tentang peran strategis dan menentukan oleh guru dalam mengantarkan keberhasilan pendidikan suatu negara. Keberhasilan pembaruan sekolah sangat ditentukan oleh gurunya, karena guru adalah pemimpin pembelajaran, fasilitator, dan sekaligus pusat inisiatif pembelajaran. Karenanya guru dituntut senantiasa mengembangkan diri.

Menurut Bapak Sapril Muhammad mengatakan bahwa kinerja guru di daerah terpencil jelas berbeda dengan guru yang ada di daerah perkotaan, ini disebabkan beberapa hal salah satunya adalah akses informasi yang jaraknya jauh. ${ }^{14}$ Keterlambatan informasi masih dirasakan oleh guru yang lokasi tempat tugasnya cukup jauh dari ibukota Kabupaten yang tidak terjangkau jaringan alat komunikasi selular. Sehingga terkadang informasi pelatihan ataupun rapat-rapat sering terlambat diketahui.

Guru adalah salah satu komponen pendidikan yang memegang peran penting dalam keberhasilan pendidikan, guru diharapkan mampu memainkan peran sebagai guru yang ideal. Masyarakat mengharapkan agar guru merupakan sosok yang dapat 'digugu' dan 'ditiru'. Banyak faktor yang memengaruhi kinerja guru, dalam penelitian ini beberapa hal yang memengaruhi kinerja guru yaitu: peran kepemimpinan kepala sekolah, pemberian kompensasi, kedisiplinan guru, dan pengembangan Sumber Daya Guru.

a. Peran Kepala Sekolah

Tugas kepala sekolah sebagai manajer adalah melaksanakan fungsi-fungsi manajemen yang berupa perencanaan, pengorganisasian, pelaksanaan dan mengevaluasi kinerja guru. Untuk menyusun rencana kinerja guru, kepala sekolah melibatkan semua unsur personalia sekolah. Dengan diterapkannya manajemen

\footnotetext{
${ }^{14}$ Sapril Mahmud, Kepala Sekolah SMP 10 Kecamatan Liukang Tupabbiring Utara Kabupaten Pangkep, Wawancara, Pangkep 10 Mei 2016
} 
sumber daya manusia oleh kepala sekolah atau dalam istilah manajemennya adalah manajer telah direspon oleh tenaga pendidik yang ada.

Kepala sekolah merupakan salah satu komponen pendidikan yang berpengaruh dalam meningkatkan kinerja guru. Kepala sekolah bertanggung jawab atas penyelenggaraan kegiatan pendidikan, administrasi sekolah, pembinaan tenaga kependidikan lainnya, dan pendayagunaan serta pemeliharaan sarana dan prasarana. Hal tersebut menjadi lebih penting sejalan dengan semakin kompleksnya tuntutan tugas kepala sekolah, yang menghendaki dukungan kinerja yang semakin efektif dan efisien.

Menurut Bapak Syamsuddin Nyonri bahwa kinerja guru di SMP 5 di Kecamatan Liukang Tupabbiring Utara Kabupaten Pangkep sudah cukup baik namun masih perlu didukung dengan sarana dan prasarana yang lengkap, begitu juga dukungan kepala sekolah sangat perlu sebagai pemberi motivasi dalam proses pembelajaran.

Kepala sekolah sebagai pemimpin lembaga pendidikan memiliki andil besar dalam menciptakan suasana kondusif yang ada dalam lingkungan kerjanya. Suasana kondusif tersebut merupakan faktor yang terpenting dalam menciptakan guru yang berprestasi. Guru sebagai pendidik memiliki peran yang sangat penting terhadap kemajuan bangsa ini, guru juga sebagai salah satu faktor penentu keberhasilan pendidikan. Tenaga pendidikan terutama guru merupakan jiwa dari sekolah' . Oleh karena itu, peningkatan profesionalisme tenaga kependidikan mulai dari analisis kebutuhan, perencanaan, pengembangan, evaluasi kinerja, hubungan kerja sampai pada imbal jasa, merupakan garapan penting bagi seorang kepala sekolah.

Guru sangat berperan dalam menentukan kualitas lulusan. Artinya untuk menghasilkan lulusan yang berkualitas diperlukan guru dengan kualitas dan prestasi maksimal. Sedangkan guru dengan kualitas dan prestasi maksimal dapat diperoleh bila ditunjang oleh kepemimpinan yang baik.

Menurut pengamatan penulis ada beberapa hal yang perlu diperhatikan kepala sekolah dalam upaya meningkatkan kinerja guru di sekolah antara lain :

1) Kesiapan perangkat pembelajaran yang dimiliki oleh guru. Perencanaan pembelajaran yang matang ditentukan oleh ketersediaan Rencana Pelaksanaan Pembelajaran (RPP), sehingga kepala sekolah berkewajiban untuk mengontrol kesiapan perangkatn pembelajaran guru yang terdiri dari Silabus, RPP, Promes, Prosem, Penilaian Kriteria Ketuntasan Minimal (KKM) dan absensi siswa.

2) Kehadiran guru di kelas selama jam pembelajaran berlangsung, 
3) Pengorganisasian pembelajaran. Kepala sekolah memantau bagaimana upaya guru untuk menata suasana kelas agar nyaman dan menyenangkan bagi peserta didik, menggunakan metode pembelajaran yang variatif dan menampilkan media pembelajaran yang mudah dicerna dan dipahami oleh peserta didik.

4) Kepala sekolah melakukan supervisi administrasi dan akedemik terhadap guru secara berkala dan terukur sebagai bahan evaluasi perbaikan dan menentukan kebijakan untuk peningkatan kualitas pembelajaran.

5) Kepala sekolah memberikan kesempatan pada guru untuk mengikuti pelatihan baik yang dilaksanakan di sekolah, kabupaten, provinsi maupun pada tingkat nasional;

6) Kepala sekolah memberikan reward (penghargaan) pada guru yang berprestasi dan memberikan teguran pada guru yang malas dan bermasalah.

Menilai kinerja guru di sekolah bukan sebuah hal yang sederhana. Perlu sebuah komunikasi yang baik di dalam sekolah sendiri untuk membuat sebuah standar penilaian yang baik. Standar penilaian kinerja guru yang baik tidak muncul begitu saja. Perlu diupayakan kesepakatan dari pihak yang akan menilai (kepala sekolah) dan guru yang akan dinilai. Dengan demikian tercapai saling pengertian bahwa proses penilaian kinerja guru, sama sekali bukan untuk mencari-cari kesalahan tetapi semata-mata untuk peningkatan kinerja agar sekolah dapat berjalan lebih baik lagi dalam prakteknya. Serta bagaimana agar sekolah dapat membantu guru agar lebih baik lagi dalam melakukan pembelajaran di kelas.

\section{b. Pemberian Kompensasi}

Berbagai aspek bidang pekerjaan baik itu di instansi pemerintah maupun swasta dapat memberikan kepuasan bagi pegawai apabila ada program kompensasi. Dengan adanya kompensasi yang diberikan sesuai dengan haknya akan sangat memengaruhi kinerja seseorang. Untuk itu hendaknya program kompensasi ditetapkan berdasarkan prinsip adil dan wajar, sesuai dengan undang-undang perburuhan, atau sesuai dengan peraturan kerja lembaga masing-masing. Dengan adanya kompensasi yang cukup besar maka disiplin karyawan semakin baik. Mereka akan menyadari serta menaati peraturan-peraturan yang berlaku.

Dalam wawancara penulis dengan ibu Zulharyani guru SMPN 5 Satap Liukang Tupabbiring Utara mengatakan bahwa pemberian kompensasi sangat perlu kepada guru karena menjadi motivasi tersendiri dalam meningkatkan kinerjanya apalagi bagi kami guru yang mengajar di daerah terpencil tentu perlu tunjangan khusus yang lebih layak untuk membantu meningkatkan kinerja kami, karena jarak 
dari sekolah ke rumah yang cukup jauh dan transportasi ke sekolah cukup menggunakan waktu, tenaga dan biaya yang tidak sedikit. ${ }^{15}$

Menurut pengamatan penulis kompensasi kerja adalah segala sesuatu yang diterima oleh guru sebagai balas jasa untuk kerja mereka. Tujuannya pemberian kompensasi (balas jasa) adalah sebagai penanda keterikatan kerja sama, mendorong kepuasan kerja, memicu motivasi kerja guru, menciptakan iklim yang kerja yang stabil dikalangan guru, dan dapat meningkatkan kedisiplinan guru.

c. Kedisiplinan Guru

Disiplin adalah kesadaran dan kesediaan seseorang menaati semua peraturan organisasi dan norma-norma sosial yang berlaku. Adapun arti kesadaran adalah sikap seseorang yang secara sukarela menaati semua peraturan dan sadar akan tugas dan tanggung jawabnya. Sedangkan arti kesediaan adalah suatu sikap, tingkah laku, dan perbuatan seseorang yang sesuai dengan peraturan perusahaan baik yang tertulis maupun tidak.

Dalam kehidupan sehari-hari dikenal ada tiga jenis disiplin yaitu; disiplin diri, disiplin belajar dan disiplin kerja. Disiplin kerja merupakan kemampuan seseorang untuk secara teratur, tekun secara terus-menerus dan bekerja sesuai dengan aturanaturan yang berlaku dengan tidak melanggar aturan-aturan yang sudah ditetapkan. Disiplin juga merupakan salah satu fungsi manajemen sumber daya manusia yang penting dan merupakan kunci terwujudnya tujuan, karena tanpa adanya disiplin maka sulit mewujudkan tujuan yang maksimal.

Melalui disiplin pula timbul keinginan dan kesadaran untuk menaati peraturan organisasi dan norma sosial. Namun tetap pengawasan terhadap pelaksanaan disiplin tersebut perlu dilakukan. Disiplin kerja adalah persepsi guru terhadap sikap pribadi guru dalam hal ketertiban dan keteraturan diri yang dimiliki oleh guru dalam bekerja di sekolah tanpa ada pelanggaran-pelanggaran yang merugikan dirinya, orang lain, atau lingkungannya. Berdasarkan uraian di atas maka menurut penulis disiplin kerja yang perlu diperhatikan adalah :

1) Disiplin terhadap tugas kedinasan misalnya: mentaati peraturan kerja, menyiapkan kelengkapan mengajar, dan melaksanakan tugas-tugas pokok.

2) Disiplin terhadap waktu misalnya: menepati waktu tugas, memanfaatkan waktu dengan baik, dan menyelesaikan tugas tepat waktu.

\footnotetext{
${ }^{15}$ Zulharyani H, Guru di SMPN 5 Satap Liukang Tupabbiring Utara Kabupaten Pangkep , Wawancara, Pangkep 24 Juli 2016.
} 
3) Disiplin terhadap suasana kerja misalnya: memanfaatkan lingkungan sekolah, menjalin hubungan yang baik, dan menjaga keseimbangan antara hak dan kewajiban.

4) Disiplin di dalam melayani masyarakat misalnya: melayani peserta didik, melayani orang tua peserta didik, dan lain lain.

Menurut Bapak Takdir dalam upaya meningkatkan kinerja guru perlu dimulai dengan kesadaran terhadap pentingnya kedisiplinan, sehingga guru yang disiplin akan memotivasi keaktifan peserta didik dalam proses pembelajaran. ${ }^{16}$

Disiplin dalam melaksanakan tugas memang sangat diperlukan, penghargaan terhadap waktu, dalam hal ini menjunjung tinggi kedisiplinan terhadap waktu. Kualitas pendidikan di Indonesia akan lebih baik jika memperbaiki pola disiplin yang dimulai dari guru sebagai sosok penanam benih keteladanan kepada generasi bangsa.

\section{d. Pengembangan Sumber Daya Manusia (SDM)}

Upaya meningkatkan kualitas pendidikan membutuhkan waktu yang panjang, serangkaian proses yang teratur dan sistematis, karena terkait dengan berbagai aspek kehidupan bangsa. Kualitas pendidikan tersebut perlu disesuaikan dengan perkembangan zaman. Perkembangan zaman yang makin pesat membawa perubahan alam pikir manusia, termasuk di dalamnya perubahan paradigma dalam meningkatkan kualitas pendidikan. Pengembangan kualitas Sumber Daya Manusia (SDM) sebagai suatu proses pembudayaan bangsa bertujuan untuk meningkatkan kualitas manusia Indonesia yang menguasai pengetahuan, keterampilan, keahlian serta wawasan yang sesuai dengan perkembangan ilmu pengetahuan dan teknologi.

Sumber daya manusia berperan besar bagi kesuksesan suatu organisasi pendidikan. Manajer merancang dan membuat organisasi sehingga dapat bertahan dan berhasil mencapai tujuan. Manajemen sumber daya manusia merupakan salah satu bidang dari manajemen umum yang meliputi segi-segi perencanaan, pengorganisasian, pelaksanaan dan pengendalian. Guru diposisikan sebagai garda terdepan dan posisi sentral di dalam pelaksanaan proses pembelajaran. Berkaitan dengan itu, maka guru akan menjadi bahan pembicaraan banyak orang, dan tentunya tidak lain berkaitan dengan kinerja guru. dapat diambil kesimpulan bahwa penerapan manajemen sumber daya manusia dalam lingkup sekolah diakui sangat

\footnotetext{
${ }^{16}$ Takdir, Guru di SMP 5 Kecamatan Liukang Tupabbiring Utara Kabupaten Pangkep, Wawancara, Pangkep 20 Juli 2016.
} 
penting. Karena setiap guru memiliki kinerja yang perlu di kembangkan dan dikelola.

Pengembangan sumber daya manusia merupakan suatu kebutuhan yang harus dilakukan secara terus menerus. Persaingan yang ketat antar lembaga pendidikan merupakan tantangan yang makin berat. Untuk itu tidak ada pilihan lain selain peningkatan kualitas sumber daya manusia tenaga pendidik untuk menghadapi persaingan yang ketat tersebut.

Sumber daya manusia sangat berperan dalam menentukan kemajuan suatu negara. Walaupun negara mempunyai sumber daya alam yang sangat melimpah ruah tapi kalau tidak ditopang atau didukung dengan sumber daya manusia yang berkualitas, negara tersebut tidak akan bisa maju. Terdapat banyak sumber daya dalam manajemen yang terlibat dalam organisasi atau lembaga pendidikan, antara lain ada yang berupa: manusia, sarana prasarana, biaya, teknologi, dan informasi. Namun demikian, sumber daya yang paling penting dalam pendidikan adalah sumber daya manusia. Adapun apabila dilihat secara mikro atau dalam ruang lingkup suatu lembaga, manusia merupakan sumber daya yang paling penting dalam usaha organisasi untuk mencapai keberhasilan. Sumber daya manusia inilah yang akan menunjang organisasi dengan berbagai karya, bakat, kreatifitas, dan dorongan. Betapapun sempurnanya aspek teknologi dan ekonomi tanpa aspek manusia akan sulit rasanya tujuan-tujuan organisasi dapat tercapai.

Guru adalah kondisi yang diposisikan sebagai garda terdepan dan posisi sentral di dalam pelaksanaan proses pembelajaran. Berkaitan dengan itu, maka guru akan menjadi bahan pembicaraan banyak orang, dan tentunya memiliki kaitan erat dengan kinerja, totalitas dedikasi dan loyalitas pengabdiannya. Guru adalah salah satu komponen penting dalam proses belajar mengajar, yang ikut berperan dalam usaha pembentukan sumber daya manusia yang potensial dibidang pembangunan. Oleh karena itu, guru yang merupakan salah satu unsur dibidang kependidikan harus berperan secara aktif dan menempatkan kedudukannya sebagai tenaga profesional, sesuai dengan tuntutan masyarakat yang semakin berkembang.

Guru tidak semata-mata sebagai pengajar yang melakukan transfer ilmu pengetahuan, tetapi juga sebagai pendidik yang melakukan transfer nilai-nilai sekaligus sebagai pembimbing yang memberikan pengarah dan menuntun peserta didik dalam belajar.

Mengingat bahwa guru merupakan faktor yang amat penting dalam pendidikan, maka proses pengembangan sumber daya manusia harus dilaksanakan dengan meningkatkan kompetensi pedagogik, kompetensi profesionalisme, kompetensi kepribadian dan kompetensi sosial sehingga mampu mengangkat citra pendidikan di daerah kepulauan. 
Sekaitan dengan kinerja guru, telah diamanatkan dalam Peraturan Pemerintah Nomor 74 Tahun 2008 beberapa hal yang mencakup beban kerja guru yang meliputi; guru bertugas untuk merencanakan pembelajaran, melaksanakan pembelajaran, menilai hasil pembelajaran, membimbing dan melatih peserta didik serta melaksanakan tugas tambahan lainnya.

Menurut Bapak Takdir bahwa kinerja guru di SMPN 5 Satap Liukang Tupabbiring Utara masih jauh dari apa yang diharapkan tetapi semoga dengan adanya tunjangan khusus dari pemerintah menjadi motivasi dalam pengembangan diri (SDM) tenaga pengajar di Kecamatan Liukang Tupabbiring Utara Kabupaten Pangkep. ${ }^{17}$

Upaya pengembangan sumber daya manusia tenaga pendidik di wilayah Liukang Tupabbiring Utara selama ini dilakukan dengan cara mengikuti pelatihanpelatihan pendidikan, seminar dan workshop, bimbingan teman sejawat maupun hasil supervisi dari kepala sekolah. Peran kepala sekolah sebagai penentu kebijakan dilingkup sekolah sangat berpengaruh pada upaya peningkatan sumber daya manusia, utamanya dalam hal koordinasi dan komunikasi kepada Dinas Pendidikan dan Pemerintah Daerah untuk menambah alokasi anggaran pengembangan SDM guru dimasing-masing sekolah.

Berdasarkan pengamatan penulis, di kecamatan Liukang Tupabbiring Utara terdapat oragnisasi profesi guru yang cukup aktif melaksanakan kegiatan. Diantaranya adalah organisasi Musyawarah Guru Mata Pelajaran (MGMP). Organisasi ini bersifat non struktural yang bertujuan sebagai forum komunikasi antar guru yang mengampu mata pelajaran yang sama. Pertemuan rutin dilaksanakan dua kali dalam sebulan, untuk membahas berbagai masalah dan kendala yang ditemui oleh tenaga pendidik dalam pelaksanaan tugasnya sehari-hari di sekolah. Keberadaan organisasi ini sangat terasa manfaatnya dikalangan guru karena bisa menjadi wahana berbagi pengalaman, dan juga saling berbagi pengetahuan tentang informasi seputar pendidkan yang mutakhir.

Dikalangan kepala sekolah juga memiliki wadah komunikasi yaitu Musyawarah Kerja Kepala Sekolah (MKKS) SMP Kecamatan Liukang Tupabbiring Utara yang menghimpun seluruh kepala sekolah setingkat SMP/sederajat yang bertugas di Kecamatan Liukang Tupabbiring Utara. Sama seperti MGMP, organisasi ini juga bersifat non struktural bertujuan untuk menjadi wadah silaturahmi dan saling bertukar informasi seputar problematika pendidikan yang dihadapi ditempat tugas masing-masing. Wadah ini juga rutin mengadakan

\footnotetext{
${ }^{17}$ Takdir, Guru di SMP 5 Kecamatan Liukang Tupabbiring Utara Kabupaten Pangkep, Wawancara, Pangkep 20 Juli 2016.
} 
pertemuan setiap bulannya dan berfungsi sebagai alat evaluasi kemajuan pendidikan di kecamatan liukang tupabbiring utara.

\section{Dampak Pemberian Tunjangan Khusus Daerah Terpencil Dalam Meningkatkan Kinerja Guru SMP di Kecamatan Liukang Tupabbiring Utara Kabupaten Pangkep}

\section{Penilaian Kinerja Guru}

Kepala sekolah sebagai pimpinan dalam unit kerja sekolah memiliki salah satu tugas pokok yaitu melakukan evaluasi terhadap kinerja guru, penilaian kinerja yang dilaksanakan setiap tahun pelajaran. hasil dari evaluasi tersebut menjadi pedoman dalam pengembangan kualitas pembelajaran untuk mewujudkan pembelajaran yang sesuai dengan tujuan kurikulum nasional.

Seperti penuturan Djihadu Ridha Halid selaku Kepala Sekolah SMPN 5 Satap Liukang Tupabbiring Utara berikut ini;

Di sekolah kami, penilaian kinerja guru dilaksanakan setiap akhir tahun pelajaran untuk mengetahui bagaimana perkembangan kinerja guru dalam pembelajaran, dari penilaian itu ada yang berkurang ada pula yang semakin menunjukkan perkembangan yang cukup memuaskan, untuk guru yang masih kurang dalam item penilaian tertentu kami berikan catatan perbaikan dan guru yang sudah bagus kami berikan motivasi untuk tidak cepat merasa puas dengan hasil yang diperoleh. ${ }^{18}$

Penilaian Kinerja Guru (PKG) disusun dengan berpedoman pada Peraturan Menteri Pendayagunan Aparatur Negara dan Reformasi Birokrasi (MenPAN-RB) Nomor 16 Tahun 2009 tentang Jabatan Fungsional Guru dan Angka Kreditnya. Peraturan Menteri tersebut memuat 14 item penilaian yang mencakup empat Kompetensi, yaitu kompetensi pedagogis, kompetensi profesionalisme, kompetensi sosial dan kompetensi kepribadian.

Hasil Penilaian Kinerja Guru kepada guru penerima tunjangan daerah terpencil di Kecamatan Liukang Tupabbiring Utara tahun pelajaran 2015/2016 tergambar dari tabel di bawah ini:

${ }^{18}$ Djihadu Ridha Halid, Kepala Sekolah di SMPN 5 Kecamatan Liukang Tupabbiring Utara Kabupaten Pangkep, Wawancara, Pangkep 20 Juli 2016. 


\section{Tabel Penilaian Kinerja Guru (PKG) Penerima Tunjangan Khusus} Tahun Pelajaran 2015 / 2016

\begin{tabular}{|c|c|c|c|c|c|c|}
\hline No & Nama Guru & NIP / NUPTK & Pangkat/Gol & Unit Kerja & Nilai PKG & Deskripsi \\
\hline 1 & $\begin{array}{l}\text { Syamsuddin Nyonri } \\
\text { S.Pd }\end{array}$ & $\begin{array}{l}198109192009021001 / \\
8251759661200023\end{array}$ & Penata III/c & $\begin{array}{l}\text { SMPN } 5 \text { Satap Liukang } \\
\text { Tupabbiring Utara }\end{array}$ & 94,6 & Amat baik \\
\hline 2 & Takdir S.Pd & $\begin{array}{l}198306092009021005 / \\
6941761662110062\end{array}$ & Penata III/c & $\begin{array}{l}\text { SMPN } 5 \text { Satap Liukang } \\
\text { Tupabbiring Utara }\end{array}$ & 94,6 & Amat baik \\
\hline 3 & Zulharyani H. S.Pd & $\begin{array}{l}198301282009022005 / \\
4460761662300062\end{array}$ & Penata III/c & $\begin{array}{l}\text { SMPN } 5 \text { Satap Liukang } \\
\text { Tupabbiring Utara }\end{array}$ & 94,6 & Amat baik \\
\hline 4 & Musliadi S.Pd & $\begin{array}{l}198504012009021004 / \\
2733763665110052\end{array}$ & Penata III/c & $\begin{array}{l}\text { SMPN } 10 \text { Satap } \\
\text { Liukang Tupabbiring } \\
\text { Utara }\end{array}$ & 87,4 & Baik \\
\hline 5 & Usman S.Pd & $\begin{array}{l}\text { 198208112009021004/ } \\
7440760661200023\end{array}$ & Penata III/c & $\begin{array}{l}\text { SMPN 4 Satap Liukang } \\
\text { Tupabbiring Utara }\end{array}$ & 93,5 & Amat baik \\
\hline 6 & $\begin{array}{l}\text { Hermawati Usman } \\
\text { S.Pd, M.Pd }\end{array}$ & $\begin{array}{l}\text { 198512212009022004/ } \\
7553763664210063\end{array}$ & Penata III/c & $\begin{array}{l}\text { SMPN } 4 \text { Satap Liukang } \\
\text { Tupabbiring Utara }\end{array}$ & 93,4 & Amat baik \\
\hline 7 & Dalmays Majid S.Pd & $\begin{array}{l}\text { 198403192011012006/ } \\
7651762664300042\end{array}$ & Penata III/c & $\begin{array}{l}\text { SMPN } 6 \text { Satap Liukang } \\
\text { Tupabbiring Utara }\end{array}$ & 83,9 & Baik \\
\hline 8 & Ruslan S.Pd & $\begin{array}{l}198404032009021004 / \\
6735762664110062\end{array}$ & Penata III/c & $\begin{array}{l}\text { SMPN 6 Satap Liukang } \\
\text { Tupabbiring Utara }\end{array}$ & 85,7 & Baik \\
\hline
\end{tabular}

Sumber data: Arsip Individu Penilaian Kinerja Guru (PKG) SMP Tahun Pelajaran 2015 / 2016

Secara umum dari akumulasi nilai PKG, guru penerima tunjangan daerah terpencil yang bertugas di beberapa SMP di wilayah Kecamatan Liukang Tupabbiring Utara memiliki kinerja yang cukup baik. Hasil tersebut tergambar dari tabel di atas dimana nilai rata-rata berada pada domain baik dan amat baik.

Secara lebih rinci penulis mengemukakan data berdasarkan 14 item penilaian yang dilaksanakan kepada guru SMPN 5 Satap Liukang Tupabbiring Utara pada akhir tahun pelajaran 2015 / 2016 sebagai berikut:

Pemetaan Kompetensi dalam Penilaian Kinerja Guru (PKG)

SMPN 5 Satap Liukang Tupabbiring Utara Tahun Pelajaran 2015/2016

\begin{tabular}{|c|l|c|c|c|}
\hline \multirow{2}{*}{ No } & \multicolumn{1}{|c|}{ Indikator Penilaian PKG } & \multicolumn{3}{|c|}{ Nilai yang diperoleh } \\
\cline { 3 - 5 } & \multicolumn{1}{|c|}{$\begin{array}{c}\text { Syamsuddin } \\
\text { Nyonri S.Pd }\end{array}$} & $\begin{array}{c}\text { Zulharyani } \\
\text { H, S.Pd }\end{array}$ & Takdir S.Pd \\
\hline 1 & $\begin{array}{l}\text { Menguasai karakteristik peserta } \\
\text { didik }\end{array}$ & 4 & 4 & 4 \\
\hline 2 & $\begin{array}{l}\text { Menguasai teori belajar dan } \\
\text { prinsip-prinsip pembelajaran yang } \\
\text { mendidik }\end{array}$ & 4 & 4 & 4 \\
\hline 3 & Pengembangan kurikulum & 4 & 4 & 4 \\
\hline
\end{tabular}




\begin{tabular}{|c|c|c|c|c|}
\hline 4 & $\begin{array}{l}\text { Kegiatan pembelajaran yang } \\
\text { mendidik }\end{array}$ & 4 & 4 & 4 \\
\hline 5 & Pengembangan potensi anak didik & 4 & 4 & 3 \\
\hline 6 & Komunikasi dengan anak didik & 3 & 4 & 4 \\
\hline 7 & Penilaian dan evaluasi & 4 & 4 & 3 \\
\hline 8 & $\begin{array}{l}\text { Bertindak sesuai dengan norma } \\
\text { agama, hukum, sosial dan } \\
\text { kebudayaan nasional }\end{array}$ & 4 & 4 & 4 \\
\hline 9 & $\begin{array}{l}\text { Menunjukkan pribadi yang dewasa } \\
\text { dan teladan }\end{array}$ & 4 & 3 & 4 \\
\hline 10 & $\begin{array}{l}\text { Etos kerja, tanggung jawab yang } \\
\text { tinggi dan rasa bangga menjadi } \\
\text { guru }\end{array}$ & 4 & 4 & 4 \\
\hline 11 & $\begin{array}{l}\text { Bersikap inklusif, bertindak } \\
\text { obyektif serta tidak diskriminatif }\end{array}$ & 4 & 4 & 4 \\
\hline 12 & $\begin{array}{l}\text { Komunikasi dengan sesama guru, } \\
\text { tenaga kependidikan, orang tua, } \\
\text { peserta didik, dan masyarakat }\end{array}$ & 4 & 3 & 4 \\
\hline 13 & $\begin{array}{l}\text { Penguasaan materi, struktur, } \\
\text { konsep, dan pola pikir keilmuan } \\
\text { yang mendukung pelajaran yang } \\
\text { diampu }\end{array}$ & 3 & 4 & 4 \\
\hline 14 & $\begin{array}{l}\text { Mengembangkan keprofesionalan } \\
\text { melalui tindakan yang reflektif }\end{array}$ & 3 & 3 & 3 \\
\hline
\end{tabular}

Sumber data: Lembar Arsip Penilaian Kinerja Guru (PKG) SMPN 5 Satap Liukang Tupabbiring Utara Tahun Pelajaran 2015 / 2016

Berdasarkan pengamatan penulis terhadap guru penerima tunjangan daerah terpencil di SMPN 5 Satap Liukang Tupabbiring Utara, capaian nilai amat baik dari ketiga guru tersebut memang ditunjang dengan kemampuan guru tersebut dalam mengelola proses pembelajaran yang meliputi perencanaan pembelajaran, pengorganisasian pembelajaran dan penggerakan pembelajaran.

Guru penerima tunjangan terpencil yang ada di SMPN 5 Satap Liukang Tupabbiring terlihat memiliki kedekatan emosional yang cukup bagus dengan siswa dan orang tua siswa, hal tersebut terlihat dari sikap antusias peserta didik yang seringkali berkunjung ke rumah dinas guru pada waktu sore hari, suasana keakraban juga terbangun dari kebiasaan guru dan siswa bersama-sama bermain olahraga bola volly maupun sepak takraw bersama warga di sekitar lingkungan sekolah. 
Selain itu berikut ini data hasil penilaian kinerja guru yang dilaksanakan pada guru penerima tunjangan daerah terpencil di SMPN 6 Satap Liukang Tupabbiring Utara yaitu:

Pemetaan Kompetensi dalam Penilaian Kinerja Guru (PKG)

SMPN 6 Satap Liukang Tupabbiring Utara Tahun Pelajaran 2015/2016

\begin{tabular}{|c|c|c|c|}
\hline \multirow{2}{*}{ No } & \multirow[b]{2}{*}{ Indikator Penilaian PKG } & \multicolumn{2}{|c|}{ Nilai yang diperoleh } \\
\hline & & $\begin{array}{l}\text { Dalmays Majid } \\
\text { S.Pd }\end{array}$ & Ruslan S.Pd \\
\hline 1 & Menguasai karakteristik peserta didik & 4 & 4 \\
\hline 2 & $\begin{array}{l}\text { Menguasai teori belajar dan prinsip-prinsip } \\
\text { pembelajaran yang mendidik }\end{array}$ & 4 & 4 \\
\hline 3 & Pengembangan kurikulum & 3 & 4 \\
\hline 4 & Kegiatan pembelajaran yang mendidik & 3 & 3 \\
\hline 5 & Pengembangan potensi anak didik & 3 & 4 \\
\hline 6 & Komunikasi dengan anak didik & 3 & 4 \\
\hline 7 & Penilaian dan evaluasi & 3 & 4 \\
\hline 8 & $\begin{array}{l}\text { Bertindak sesuai dengan norma agama, } \\
\text { hukum, sosial dan kebudayaan nasional }\end{array}$ & 3 & 4 \\
\hline 9 & $\begin{array}{l}\text { Menunjukkan pribadi yang dewasa dan } \\
\text { teladan }\end{array}$ & 4 & 4 \\
\hline 10 & $\begin{array}{l}\text { Etos kerja, tanggung jawab yang tinggi dan } \\
\text { rasa bangga menjadi guru }\end{array}$ & 3 & 2 \\
\hline 11 & $\begin{array}{l}\text { Bersikap inklusif, bertindak obyektif serta } \\
\text { tidak diskriminatif }\end{array}$ & 3 & 4 \\
\hline 12 & $\begin{array}{l}\text { Komunikasi dengan sesama guru, tenaga } \\
\text { kependidikan, orang tua, peserta didik, dan } \\
\text { masyarakat }\end{array}$ & 4 & 3 \\
\hline 13 & $\begin{array}{l}\text { Penguasaan materi, struktur, konsep, dan } \\
\text { pola pikir keilmuan yang mendukung } \\
\text { pelajaran yang diampu }\end{array}$ & 3 & 2 \\
\hline 14 & $\begin{array}{l}\text { Mengembangkan keprofesionalan melalui } \\
\text { tindakan yang reflektif }\end{array}$ & 4 & 2 \\
\hline
\end{tabular}

Sumber data: Lembar Arsip Penilaian Kinerja Guru (PKG) SMPN 6 Satap Liukang

Tupabbiring Utara Tahun Pelajaran 2015 / 2016

2. Meningkatkan Disiplin Kerja (kehadiran guru)

Menurut Bapak Takdir bahwa dengan adanya tunjangan khusus daerah terpencil sangat memotivasi keaktifan tenaga pendidik yang ditempatkan di daerah 
terpencil terkhusus di Kecamatan Liukang Tupabbiring Utara. ${ }^{19}$ Zulharyani $\mathrm{H}$ mengatakan kinerja guru setelah pemberian tunjangan meningkat, guru lebih memiliki semangat dalam menjalankan proses pembelajaran di kelas dan menjadikan guru lebih fokus mengajar karena tidak lagi membagi waktu untuk mencari pekerjaan lain. ${ }^{20}$ Dan menurut Syamsuddin Nyonri mengatakan bahwa dengan tambahan dana dalam hal ini pemberian tunjangan, kinerja guru khususnya di SMPN 5 Satap Liukang Tupabbiring Utara dapat memotivasi kehadiran guru. ${ }^{21}$

Dari beberapa wawancara maka menurut kesimpulan penulis bahwa pemberian tunjangan khusus mnjadi salah satu faktor yang dapat meningkatkan kedisiplinan guru khususnya meningkatkan kehadiran guru di sekolah. Kedisiplinan seorang guru sangat penting dalam proses pembelajaran karena intensitas kehadiran guru mengisi jam pembelajaran di kelas memiliki pengaruh terhadap peningkatan kualitas peserta didik khususnya di daerah terpencil.

Berdasarkan pengamatan penulis terkait dengan kedisiplinan guru dikepulauan sangat dipengaruhi oleh dua faktor yaitu; Pertama ketersediaan sarana transportasi rutin yang akan mengantarkan guru menuju pulau tempatnya bertugas. Sarana transportasi yang selama ini digunakan adalah perahu tradisional Jolloro yang menjadi sarana transportasi publik yang paling utama, masyarakat memanfaatkan jasa perahu tradisional ini untuk menempuh perjalanan menuju pulau dengan waktu tempuh untuk pulau terdekat minimal 1 jam dan untuk pulau terjauh dalam wilayah kecamatan Liukang Tupabbiring Utara dapat ditempuh minimal 4 jam. faktor yang Kedua yaitu kondisi cuaca, apabila kondisi cuaca buruk melanda perairan pangkep, angin kencang dan ombak besar, maka mau tidak mau guru harus menunda keberangkatan menuju pulau untuk menjalankan tugasnya, karena faktor keselamatan jiwa guru yang mengajar dikepulauan masih lebih diutamakan demi keberlangsungan proses pembelajaran.

3. Meningkatkan Motivasi Kerja Guru

Bapak Takdir mengatakan bahwa penerima tunjangan khusus daerah terpencil menjadi salah satu pemicu dalam peningkatan sumber daya manusia (SDM)

\footnotetext{
${ }^{19}$ Takdir, Guru di SMP 5 Kecamatan Liukang Tupabbiring Utara Kabupaten Pangkep, Wawancara, Pangkep 20 Juli 2016.

${ }^{20}$ Zulharyani, Guru di SMP 5 Kecamatan Liukang Tupabbiring Utara Kabupaten Pangkep , Wawancara, Pangkep 24 Juli 2016.

${ }^{21}$ Syamsuddin Nyonri, Guru di SMP 5 Kecamatan Liukang Tupabbiring Utara Kabupaten Pangkep, Wawancara, Pangkep 24 Juli 2016.
} 
terutama dalam pengenalan informasi dan tekhnologi (IT) termasuk mempelajari penggunaan laptop dan internet sehingga guru bisa memperkaya wawasannya. ${ }^{22}$

Wawancara penulis dengan Zulharyani mengatakan $\mathrm{H}$ setelah pemberian Menurut penulis motivasi kerja sangat dipengaruhi oleh rasa aman dalam bekerja, penghasilan yang layak, gaji yang adil dan kompetitif, kondisi lingkungan kerja yang nyaman dan menyenangkan. Motivasi kerja bisa lahir dari diri sendiri, dengan adanya kemauan keras guru untuk terus berupaya meningkatkan kualitas pembelajaran dan semangat guru untuk selalu belajar dan tanggap terhadap berbagai perkembangan teknologi pembelajaran demi tugas sebagai pendidik yang diberikan amanah untuk mencerdaskan anak-anak yang berada dikepulauan.

\section{Meningkatkan Etos Kerja Guru}

Bapak Usman mengatakan bahwa setelah pemberian tunjangan khusus maka saya merasa lebih bersemangat dalam menemukan dan mencari metode pembelajaran yang terbaru baik lewat buku maupun lewat media dan internet karena ada biaya dan dana dari pemerintah. ${ }^{23}$ Etos kerja guru yang tinggi akan banyak menentukan keberhasilan usaha dan proses pembelajaran di sekolah misalnya kedisiplinan seorang guru, dedikasinya kepada peserta didik, dan lainlain. Karena itu, masalah tersebut menarik untuk diperhatikan.

Menurut Bapak Sapril Mahmud diharapkan setelah pemberian tunjangan khusus, tugas yang diemban oleh guru menjadi semakin amanah dalam menjalankan tugasnya karena menurut saya pribadi bahwa setelah pemberian tunjangan khusus ada beban tersendiri untuk memberikan yang terbaik kepada peserta didik khususnya di daerah terpencil. ${ }^{24}$

Berdasarkan pengamatan penulis, etos kerja memang sangat perlu ditanamkan pada guru di daerah terpencil, guru yang memiliki etos kerja yang tinggi akan selalu berpikir melakukan yang terbaik bagi peserta didiknya, segenap kemampuannya dicurahkan untuk hasil terbaik dalam pembelajaran. Selain itu etos kerja guru dan tenaga pendidik lainnya mutlak dibutuhkan untuk meningkatkan efesiensi dan efektifitas program yang dicanangkan segenap warga sekolah.

Guru yang mendapatkan tunjangan khusus akan menjadi teladan dalam hal etos kerja bagi guru lainnya, diharapkan dengan adanya tambahan penghasilan tersebut memacu guru untuk berusaha menerapkan prinsip kerja keras, semangat

\footnotetext{
${ }^{22}$ Takdir, Guru di SMP 5 Kecamatan Liukang Tupabbiring Utara Kabupaten Pangkep , Wawancara, Pangkep 20 Juli 2016.

${ }^{23}$ Muhammad Usman, Guru di SMP 4 Kecamatan Liukang Tupabbiring Utara Kabupaten Pangkep , Wawancara, Pangkep 25 Juli 2016.

${ }^{24}$ Sapril Mahmud, Guru di SMP 10 Kecamatan Liukang Tupabbiring Utara Kabupaten Pangkep, Wawancara, Pangkep 10 Mei 2016.
} 
yang tinggi untuk mencapai hasil kerja yang lebih baik dari masa sebelumnya, dan mencintai pekerjaannya selaku pendidik dengan segenap amanah mulia yang diembannya. Sebab guru yang mendapatkan tunjangan khusus tentunya berbeda dengan guru lainnya, kompensasi yang diberikan negara selayaknya dimanfaatkan untuk pengembangan diri, peningkatan kualitas pembelajaran dan untuk memenuhi kebutuhan alat penunjang pembelajaran dikelas.

5. Mendorong Guru dalam Meningkatkan Kemampuan Penerapan Metode Pembelajaran

Syamsuddin Nyonri mengatakan bahwa penerapan metode pembelajaran tidak monoton dan semakin bervariasi setelah pemberian tunjangan. Menurut Bapak Takdir bahwa penerapan metode pembelajaran di dalam kelas masih jauh dari kata maksimal jika dibandingkan dengan daerah perkotaan namun diharapkan setelah pemberian tunjangan khusus menjadi pemicu peningkatan SDM bagi teman-teman yang ada di daerah terpencil. Sedangkan Zulharyani H mengatakan bahwa setelah pemberian tunjangan khusus kemampuan guru meningkat karena guru dapat lebih leluasa dalam menemukan metode pembelajaran terbaru dan bisa menerapkannya di kelas.

Wawancara penulis dengan Bapak Musliadi mengatakan bahwa dengan adanya pemberian tunjangan khusus ini maka kemampuan guru di kelas juga berpengaruh misalnya dalam hal penerapan metode pembelajaran terbaru, guru berusaha mencari metode pembelajaran terbaru diinternet ataupun berusaha membeli buku-buku referensi yang sesuai dengan bidang studi yang diampu.

Guru mempunyai peran yang sangat penting dalam menentukan kualitas dan kuantitas pengajaran yang telah ditentukan. Oleh sebab itu, guru harus memikirkan dan membuat perencanaan secara rutin dan terprogram dalam usaha meningkatkan kualitas mengajar dan kesempatan belajar bagi peserta didik.

Untuk itu dituntut adanya inovasi dalam pengelolaan kelas. Guru sebagai penanggung jawab kegiatan belajar mengajar harus penuh inisiatif dan kreatif dalam kegiatan belajar mengajar, karena gurulah yang mengetahui secara pasti situasi dan kondisi kelas terutama keadaan anak dengan segala latar belakangnya.

Berdasarkan temuan penulis dilapangan, mayoritas guru penerima tunjangan khusus daerah terpencil memanfaatkan dana yang didapat untuk melengkapi media pembelajaran berupa laptop, modem internet dan printer. Tuntutan kurikulum yang semakin kompleks mengharuskan guru memiliki kemampuan mengoperasikan teknologi dalam pembelajaran, menuntut guru agar menguasai metode pembelajaran berbasis TIK (Teknologi, Informasi dan Komunikasi). 
6. Mendorong Guru dalam Meningkatkan Penguasaan Media Pembelajaran Berbasis Tekhnologi

Takdir mengatakan sangat banyak kemajuan, karena dengan adanya tunjangan khusus daerah terpencil menjadi daya tambah dalam pemenuhan kebutuhan IT (Informasi Tekhnologi) atau pembelian alat IT seperti laptop dan internet sehingga media-media pembelajaran bisa didapatkan diinternet dan bisa diterapkan di sekolah masing-masing. Menurut Zulharyani $\mathrm{H}$ guru lebih menguasai teknologi pembelajaran karena guru dapat membeli alat penunjang pembelajaran setelah menerima tunjangan. Sedangkan Syamsuddin Nyonri mengatakan bahwa setelah pemberian tunjangan khusus penguasaan media sudah baik dan meningkat apalagi jika didukung sarana pembelajaran TIK yang dimiliki di sekolah masing-masing.

Faktor yang memengaruhi keberhasilan sekolah dalam melakukan proses belajar mengajar adalah pembelajaran. Pembelajaran berkaitan dengan aktifitas proses belajar mengajar yang dilakukan oleh guru, oleh karena itulah dalam menunjang pelaksanaan pembelajaran maka sangatlah ditentukan oleh adanya model atau desain pembelajaran.

Searah dengan kemajuan teknologi informasi dalam peningkatan kualitas pembelajaran dan manajemen sekolah, maka setiap guru di sekolah perlu menerapkan tata kelola pembelajaran yang berbasis informasi dan teknologi meskipun menurut Bapak Musliadi bahwa penguasaan media di daerah terpencil masih kurang karena sarana dan prasarana belum mendukung 100 persen.

Penulis menemukan kondisi dimana yang menjadi hambatan terbesar dalam penerapan metode pembelajaran berbasis TIK adalah minimnya ketersediaan energi listrik dikepulauan. Listrik dikepulauan masih bergantung pada genset, yang sangat terbatas jam pengoperasiannya karena sumber bahan bakar genset berupa solar yang cukup mahal. Listrik hanya menyala selama 4 hingga 6 jam disaat malam hari. Sehingga penggunaan alat elektronik disiang hari sangat terbatas.

Sekolah di kepulauan mengandalkan genset yang diperoleh dari pembelian dengan menggunakan dana sekolah. Genset berbahan bakar bensin yang dipergunakan setiap hari untuk mendukung pembelajaran yang memanfaatkan media komputer/laptop. Tingginya biaya bahan bakar mengakibatkan banyak sekolah yang tidak mampu menggunakan genset setiap harinya, sehingga pembelajaran dengan media komputer/laptop hanya berlangsung pada hari-hari tertentu. 


\section{Solusi Perbaikan Kinerja Guru SMP di Daerah Terpencil}

Bapak Takdir Mengatakan bahwa ketika kesejahteraan guru diperhatikan kami percaya akan menjadi motivasi keaktifan dan pengembangan SDM guru yang ada di daerah terpencil.

Senada dengan itu, ibu Zulharyani $\mathrm{H}$ mengatakan kinerja guru di daerah terpencil dapat ditingkatkan dengan memberikan tunjangan khusus terpencil sehingga mereka dapat menggunakannya untuk menemukan metode dan materimateri pembelajaran yang lebih baik. Sedangkan menurut Bapak Syamsuddin Nyonri mengatakan bahwa selain pemberian tunjangan khusus dapat meningkatkan kinerja guru pihak sekolah juga perlu menambah sarana dan prasarana yang sudah ada. $^{25}$

Menurut bapak Musliadi solusi dalam perbaikan kinerja guru yaitu perlu adanya pendampingan, pelatihan bagi guru khususnya di daerah terpencil, sarana dan prasarana juga di daerah kepulauan harus dilengkapi. ${ }^{26}$ Muhammad Usman juga mengatakan hal yang sama bahwa perlu lebih banyak dilaksanakan pelatihan, pendampingan dan yang paling penting adalah ketersediaan sarana dan prasarana yang lengkap. ${ }^{27}$

Guru daerah terpencil keberadaannya harus mendapat perhatian yang serius dari pemerintah pusat maupun daerah dengan memberikan apresiasi yang sesuai dengan beban tugasnya. Tantangan yang akan dihadapi di daerah terpencil, pastinya berbeda dengan tantangan yang berada di daerah perkotaan. Mulai dari letak geografis sekolah, kehidupan masyarakat, dan karakteristik peserta didiknya.

Guru yang mengabdi di daerah terpencil pada saat melangkahkan kaki menuju tempat tugasnya, meninggalkan keluarga, berhadapan dengan berbagai resiko perjalanan yang bisa saja mengancam keselamatan jiwanya. Selain dari kondisi perjalanan menuju tempat tugas yang cukup ekstrem, guru tersebut juga harus menghadapi keterbatasan dalam hal pemenuhan kebutuhan sandang dan pangan yang masih terbatas di daerah kepulauan.

Resiko perjalanan yang dihadapi dan kesulitan pemenuhan kebutuhan hidup selama bertugas di daerah kepulauan inilah yang menjadi titik fokus manfaat dari adanya tunjangan khusus daerah terpencil kepada guru di kepulauan. Meskipun

\footnotetext{
${ }^{25}$ Syamsuddin Nyonri, Guru di SMP Kecamatan Liukang Tupabbiring Utara Kabupaten Pangkep , Wawancara, Pangkep 30 Mei 2016.

${ }^{26}$ Musliadi, Guru di SMP 10 Kecamatan Liukang Tupabbiring Utara Kabupaten Pangkep, Wawancara, Pangkep 23 Juli 2016.

${ }^{27}$ Muhammad Usman, Guru di SMP 4 Kecamatan Liukang Tupabbiring Utara Kabupaten Pangkep, Wawancara, Pangkep 25 Juli 2016.
} 
tunjangan yang setiap bulannya diberikan kepada guru tersebut jumlahnya belum sebanding dengan resiko perjalanan yang dihadapi namun nilai tersebut sangat berarti bagi guru-guru yang bertugas di kepulauan.

Keberadaan tunjangan tersebut menjadi bentuk penghargaan terhadap profesi pendidik dan sebagai salah satu bentuk kepedulian pemerintah terhadap kesejahteraan guru. Dan juga adanya tunjangan tersebut bisa menjadi nilai pembeda dan daya tarik tersendiri bagi potensi tenaga pendidik berkualitas untuk turut bersedia mengabdikan diri di daerah terpencil.

Menurut analisa penulis berdasarkan hasil pengamatan selama meneliti dikepulauan disertai hasil wawancara dengan penerima tunjangan khusus bahwa untuk perbaikan mutu dan daya saing pendidikan dikepulauan ada beberapa solusi yang bisa menjadi pertimbangan Pemerintah Daerah dan juga Pemerintah Pusat yaitu antara lain:

a) Guru diberikan kemudahan melanjutkan pendidikan untuk mengembangkan kompetensi dan SDMnya. Dan diperlukan upaya serius pemerintah daerah untuk membantu tenaga pendidik dalam pembiayaan untuk melanjutkan pendidikannya.

b) Perlu ada fasilitas transportasi khusus (kapal dinas) khusus bagi guru yang mengajar di kepulauan. Sehingga guru tidak lagi bergantung kepada transportasi publik yang mayoritas belum dilengkapi standar keamanan transportasi laut yang safety dan layak..

c) Dinas Pendidikan dan komponen pemerintah daerah perlu memperjuangkan secara serius penambahan kuota penerima tunjangan khusus agar terwujud pemerataan bagi semua guru yang berhak mendapatkan tunjangan khusus daerah terpencil

d) Kepada legislator sebagai wakil rakyat, perlu kiranya mengupayakan penerbitan Peraturan Daerah (PERDA) sebagai landasan penambahan anggaran tunjangan khusus daerah terpencil yang dialokasikan dari Anggaran Pendapatan dan Belanja Daerah (ABPBD) Kabupaten Pangkep.

e) Rekrutmen guru menjadi pegawai negeri sipil (PNS) yang berasal dari penduduk asli kepulauan yang selama ini berstatus honorer agar mereka fokus mengajar di kepulauan.

\section{KESIMPULAN}

Berdasarkan uraian dan penjelasan bab-bab sebelumnya serta hasil deskripsi, interpretasi data yang penulis lakukan dalam bab IV, maka penulis dapat mengemukakan beberapa kesimpulan akhir atas penulisan ini sebagai berikut: 
1. Pemberian tunjangan khusus daerah terpencil kepada guru-guru SMP di Kecamatan Liukang Tupabbiring Utara Kabupaten Pangkep belum merata dan transparan karena berdasarkan pengamatan penulis masih terdapat beberapa guru yang mengajar di daerah terpencil, utamanya guru yang berstatus honorer masih banyak yang belum mendapatkan tunjangan khusus sehingga diharapkan kepada pihak yang terkait untuk mengadakan pendataan kemudian diusulkan oleh kepala sekolah masing-masing ke dinas kabupaten dan diperjuangkan untuk penambahan kuota kepada Kementerian Pendidikan dan Kebudayaan.

2. Kinerja guru SMP di Kecamatan Liukang Tupabbiring Utara Kabupaten Pangkep masih belum sesuai dengan apa yang diharapkan, tetapi dengan adanya tunjangan khusus daerah terpencil telah memacu motivasi untuk pengembangan diri guru-guru yang ada di kepulauan. Secara umum, kondisi sarana dan prasarana pendidikan yang masih sangat terbatas di daerah kepulauan cukup berpengaruh pada perbaikan kualitas pembelajaran, sehingga perhatian dari pihak Pemerintah Daerah dan Pemerintah Pusat sangat dibutuhkan demi tercapainya kemajuan pendidikan di daerah kepulauan.

3. Dari pengamatan penulis adapun dampak pemberian tunjangan khusus khusus daerah terpencil pada guru-guru SMP di Kecamatan Liukang Tupabbiring Utara Kabupaten Pangkep yaitu: dapat meningkatkan disiplin kerja (kehadiran guru), memacu motivasi kerja guru, meningkatkan etos kerja guru, mendorong guru dalam meningkatkan kemampuan penerapan metode pembelajaran, mendorong guru dalam meningkatkan penguasaan media pembelajaran berbasis teknologi.

\section{DAFTAR PUSTAKA}

Alifuddin, Moh. Strategi Inovatif Peningkatan Mutu Pendidikan, Jakarta: Magnasseript Publishing, 2012.

Amnatu, Frederikus dan Aunurrahman, Implementasi Kebijakan Dalam memberikan Tambahan Penghasilan Berdasarkan Beban Kerja Guru yang Mengajar di Daerah Terpencil Se Kecamatan Lembah Bawang. FKIP Universitas Tanjung Pura Vol 2. No. 12 (Desember 2013).

Amtu, Onisimus. Membenahi Pendidikan di Wilayah Kepulauan, Cet. I; Bandung: CV. Alfabeta, 2014.

Anoraga, Pandji. Psikologi Kerja, Jakarta: PT Rineka Cipta, 1992.

As'ad, Moh. Psikologi Industri, Cet VIII; Yogyakarta: Liberty, 2003. 
Barnawi dan M. Arifin, Strategi dan Kebijaksanaan Pembelajaran Pendidikan Karakter, Yogjakarta: AR-RUZZ MEDIA, 2013.

B. Uno, Hamzah. dan Nina Lamatenggo, Teori Kinerja dan Pengukurannya, Cet II; PT. Bumi Aksara: Jakarta, 2014.

Djamarah, Syaiful Bahri. Guru dan Anak dalam Interaksi Edukatif, Jakarta: Rineka Cipta, 2000.

E. Mulyasa, Standar Kompetensi dan Sertifikasi Guru, Bandung: Remaja Rosdakarya, 2007.

Hasri, Salfen. Sekolah Efektif dan Guru Efektif, Yogyakarta: Aditya Media, 2009.

Kementerian Pendidikan dan Kebudayaan, Petunjuk Teknis Penyaluran Tunjamgan Khusus Jenjang Pendidikan Dasar, Jakarta: Direktur Pembinaan PTK Diknas. Tahun 2015

Malik, Hermen. Fajar Kebangkitan Pendidikan Daerah Tertinggal, Cet. I; Jakarta: Pustaka LP3ES, 2013.

Mangkunegara, A.A.Anwar Prabu. Manajemen Sumber Daya Manusia Perusahan Bandung: Remaja Rosda Karya, 2000.

Mudlofir, Ali. Pendidik Profesional: Konsep, Strategi, dan Aplikasinya Dalam Peningkatan Mutu Pendidikan di Indonesia, Cet. II; Rajawali Pers: Jakarta, 2013.

Mohyi, Ach. Teori Dan Perilaku Organisasi, Surabaya: UMM Press, 1999.

Prawirosentono, Kebijakan Kinerja Karyawan, Yogyakarta: BPFE, 1999.

Sagala, Syaiful. Manajemen Strategik dalam Peningkatan Mutu Pendidikan Bandung: Alfabeta, 2009.

Wijono, Sutarto. Psikologi Industry Dan Organisasi: Dalam Suatu Bidang Gerak Psikologi SumberDaya Manusia, Jakarta: Kencana Prenatal Media Group, 2010. 